\title{
Spatial dynamics and activity patterns of the fosa Cryptoprocta ferox in Ankarafantsika National Park, Madagascar: carnivores navigating a human-influenced landscape
}

\author{
Eileen Wrza, Luke Dollar, Leon Pierrot Rahajanirina \\ Viorel Popescu and Nancy J. Stevens
}

\begin{abstract}
The Vulnerable fosa Cryptoprocta ferox is the largest native carnivore in Madagascar, fulfilling a unique ecological niche in the island's remaining forests. Negative interactions with humans threaten the long-term viability of most remaining fosa populations across Madagascar. Threats to the fosa include habitat loss and persecution by humans resulting from perceived predation on domestic animals. We used GPS collars to record space use and activity patterns of five fosas in Ankarafantsika National Park, Madagascar, during the dry seasons of 2016 and 2017. The results, with up to 2,110 recorded locations per individual, indicated fosas' home ranges and movements were not limited to the forest, and all collared individuals used networks of habitat patches and corridors to navigate deforested areas. The fosas studied in Ankarafantsika National Park had significantly larger home ranges than those reported in previous studies in other protected areas. They were rarely found within village boundaries and appeared to avoid areas of human habitation, suggesting that during the study period livestock was not a significant component of the fosas' diet in this Park. Our results suggest that fosas have some flexibility that enables them to adapt to living near deforested and humandominated areas by altering their space-use patterns, but they are compensating by increasing their home range size.
\end{abstract}

Keywords Carnivore, corridor use, Cryptoprocta ferox, fosa, GPS, habitat selection, human-wildlife interactions, Madagascar

Eileen Wyza and Viorel Popescu Department of Biological Sciences, Ohio University, Athens, USA

LUKE DOLLAR $\ddagger$ Department of Environment and Sustainability, Catawba College, Salisbury, USA

Leon Pierrot Rahajanirina ${ }^{\dagger}$ Department of Animal Biology, Faculty of Sciences, University of Antananarivo, Antananarivo, Madagascar

NANCY J. Stevens* (Corresponding author, (1) orcid.org/0000-0002-2402-6526) Department of Biomedical Sciences, Heritage College of Osteopathic Medicine, Environmental Studies Program, Ohio University, 204 Grosvenor Hall, Athens, Ohio 45701, USA. E-mail stevensn@ohio.edu

${ }^{*}$ Also at: Center for Ecology and Evolutionary Studies, Ohio University, Athens, USA

¥Also at: Nicholas School of the Environment, Duke University, Durham, USA $\dagger$ Deceased

Received 4 November 2018. Revision requested 3 December 2018. Accepted 30 April 2019. First published online 23 January 2020.

\section{Introduction}

The unique forests of Madagascar are threatened by a number of anthropogenic factors including deforestation, human population growth leading to habitat loss, and introduction of exotic species (Harper et al., 2007; Zinner et al., 2014; Schüßlera et al., 2018). In many of the island's forested ecosystems, including the spiny forests, eastern rainforests, and dry deciduous forests, the fosa Cryptoprocta ferox is an apex predator. The fosa's diet includes small to medium-sized animals such as lemurs, but varies by region and season (Köhncke \& Leonhardt, 1986; Hawkins, 2003; Dollar et al., 2007; Mann et al., 2015). The fosa is generally considered solitary outside the mating season, but several recent studies present evidence of associations between some individuals (Lührs \& Kappeler, 2013; Wyza et al., 2018). Home ranges documented in previous studies were $12-89 \mathrm{~km}^{2}$ during the dry season (Hawkins, 1998; Lührs \& Kappeler, 2013), with males exhibiting spatial overlap with females and other males, and females occupying ranges that overlap with those of males but not those of other females (Hawkins, 2003). A flexible cathemeral activity pattern has been reported for fosas, with a slight preference for crepuscular hours (Albignac, 1973; Hawkins, 1998; Gerber et al., 2012).

Fosas are categorized as Vulnerable on the IUCN Red List of Threatened Species, for a combination of reasons (Hawkins, 2016). These include low population densities compared to other tropical carnivores (Rahajanirina, 2003; Hawkins \& Racey, 2005), country-wide loss of forested habitats (Gerber et al., 2012; Kotschwar Logan et al., 2015), and the introduction of other carnivore species that compete for prey and transmit diseases to fosas (Farris et al., 2015b; Pomerantz et al., 2016). Fosas are also subject to intense persecution because they are widely believed to prey on domestic animals, particularly poultry (Woodroffe \& Ginsberg, 1998; García \& Goodman, 2003; Golden, 2009; Kotschwar Logan et al., 2015; Farris et al., 2015b). Only two of Madagascar's 46 national parks are thought to be large enough to maintain viable populations (Hawkins \& Racey, 2005; Gerber et al., 2010) and fosa numbers have decreased by $30 \%$ since 1995 , with projections suggesting an additional third could be lost by 2040 (Hawkins, 2016). Research is needed urgently to inform conservation and management 
protocols if the fosa is to remain part of Madagascar's unique ecosystems.

To determine the impact of various threats on fosa populations, it is necessary to explore potential shifts in spatial and temporal behaviours. Some carnivores such as the coyote Canis latrans, the spotted hyena Crocuta crocuta and the red fox Vulpes vulpes have successfully adapted to human encroachment and thrive in areas of high human population densities, despite being persecuted (Gloor et al., 2001; Riley et al., 2003; Grubbs \& Krausman, 2009; Abay et al., 2011). It is possible that fosas are also able to adapt to habitat loss by altering their space-use patterns. Additionally, they may avoid encounters with humans by shifting their activity cycle to a nocturnal pattern.

Advances in technology such as GPS collars equipped with accelerometers enable us to explore changes in space use and activity patterns of cryptic species, including the fosa. Such collars also gather critical data on fine-scale movements, which are needed to augment studies on spatial ecology and behaviour that use other methods, particularly across heterogeneous landscapes (Morales \& Ellner, 2002; Brown et al., 2013). Furthermore, accelerometer data allow for location data to be combined with activity patterns associated with locomotion, feeding, resting and social interactions amongst collared individuals (Shepard et al., 2008; Nathan et al., 2012; Wyza et al., 2018). These methods have been used to examine behavioural alterations of another cryptic carnivore, the cougar Puma concolor, in residential areas (Wang et al., 2017), and have the potential to be expanded across a variety of taxa.

To our knowledge, this is the first study to employ GPS collars with accelerometers to examine fosa movements and activity patterns near human settlements. It is also the first study using this technology to examine fosa space use at a fine scale in the heavily human-influenced landscape of Ankarafantsika National Park. To explore human-wildlife interactions and fosa spatial ecology, we focused on three main objectives: (1) documenting home range size and habitat selection during the dry season, (2) discerning movement and activity patterns in fragmented forest landscapes, and (3) evaluating fosa spatial and temporal activity in relation to villages located within the Park. Spatial and temporal data offer insights into fosa habitat use and allow us to determine whether fosas frequently range into human settlements and prey upon domestic animals.

\section{Study area}

Ankarafantsika National Park in north-western Madagascar is a 135,000 ha dry deciduous forest (Fig. 1), with a dry season during May-October and a wet seasons during November-April (Alonso et al., 2002). The Park has been subject to severe deforestation, with $20 \%$ of forest cover

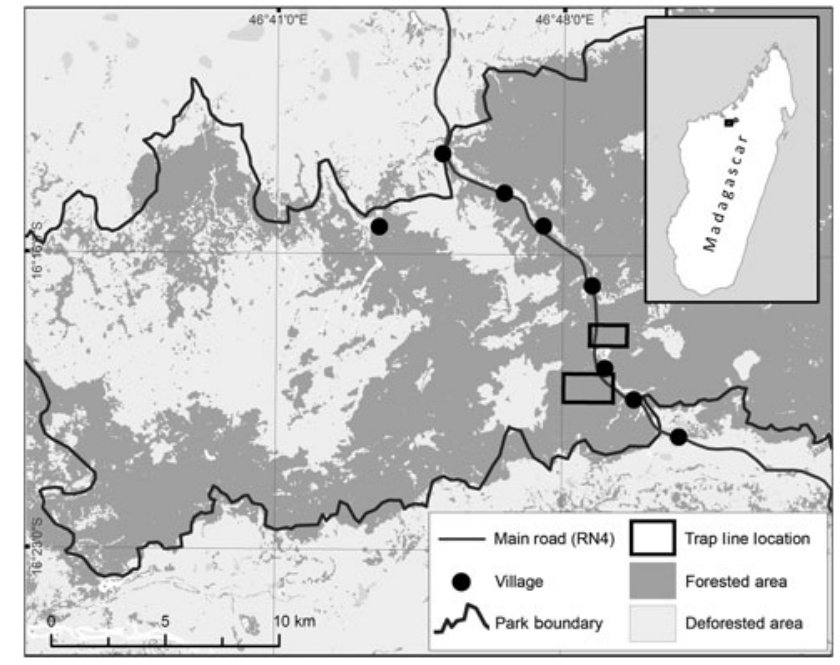

FIG. 1 Ankarafantsika National Park, Madagascar. Locations of villages and fosa Cryptoprocta ferox trap lines are shown. The main road $\mathrm{RN}_{4}$ bisects the Park.

lost during 1990-2000 (Dollar, 2006). Habitat alteration has been documented even in the most remote areas of the Park (K. Flanigan, pers. comm., 2018). Deforestation in the Park is largely a result of land conversion to cropland and pasture, carried out by people living in eight villages inside the Park and/or bordering its perimeter. Timber, charcoal and non-timber forest products are also harvested (Alonso et al., 2002). Village populations vary widely; some areas house single families, whereas the population of the largest village located just outside the Park (Andranofasika) was estimated to be 8,00o in 2001 (Cornell University, 2002). The total human population within the Park's boundaries is difficult to estimate because of the rural and scattered nature of many settlements; the estimated total village area within the Park and immediately adjacent to its borders is $12 \mathrm{~km}^{2}$. A major road (RN4) divides the park into an eastern and a western area and hinders wildlife movements, with documented roadkill mortality (Wyza et al., 2018).

\section{Methods}

\section{Fosa capture and GPS collar deployment}

We collected data in the dry seasons of 2016 (JuneSeptember) and 2017 (July-October). Fosas were trapped using bobcat traps (Tomahawk, Hazelhurst, USA) along two $2.5 \mathrm{~km}$ long trap lines, with a total of 40 traps placed 50-200 $\mathrm{m}$ apart. Trap lines were located on either side of $\mathrm{RN}_{4}$ (Fig. 1). The same trap lines were used in both years. Captured fosas were sedated with Telazol $\left(0.05 \mathrm{~cm}^{3} / \mathrm{kg}\right)$ in accordance with Institutional Animal Care and Use Committee protocols following Dollar (2006), then fitted 
with Telonics TGW-4277-4 GPS Iridium collars (220 g; Telonics, Mesa, USA). We programmed collars to take quick fix pseudoranging spatial data at 20-minute intervals, to mitigate a high failure rate anticipated because of forest cover density. Quick fix pseudoranging allows for data to be transmitted to satellites much faster than traditional GPS methods, which is ideal for tracking small mammals in densely forested habitat. We placed collars only on adults weighing at least $4,400 \mathrm{~g}$, so that collars comprised $\leq 5 \%$ of body mass. Animals were placed in a dark recovery cage and monitored until they recovered from anaesthesia, then released at the capture site.

\section{Spatial and temporal analyses}

We used only resolved locations (defined by Telonics as those with an accuracy within $30 \mathrm{~m} 98 \%$ of the time and within $10 \mathrm{~m} 80 \%$ of the time) for spatial analyses. Ranging patterns were calculated for kernel density estimates following Worton (1989), and Brownian bridge movement models following Horne et al. (2007). Kernel density estimates determine the probability of finding a given animal in a certain area, whereas Brownian bridge movement models incorporate pathways and temporal data to calculate where individuals spend the most time within a given home range. We calculated kernel density estimates of 50, 90, and 95\% with ad hoc smoothing parameters using the adehabitat $H R$ package in $R$ 3.3.2 (Calenge, 2015). We used these estimates to compare fosa home ranges in Ankarafantsika National Park with those documented in a different dry forest habitat in Kirindy Forest (Lührs \& Kappeler, 2013). We computed 50 and $95 \%$ Brownian bridge movement models using the $R$ package BBMM (Nielson et al., 2015), which allowed us to characterize individual home ranges using high resolution spatial data (20-minute intervals) without the assumption of independence that other home range estimates require. We also combined spatial and temporal data using Brownian bridge movement models, to examine pathways used by individuals within their home ranges, particularly in areas of heavy deforestation. We calculated overlaps between individuals for home ranges derived from both kernel density estimates and Brownian bridge movement models.

We determined habitat selection within each individual's home range using the semi-automatic classification plugin in QGIS 2.18.3 (Congedo, 2016). Landsat imagery from June 2016 (U.S. Geological Survey, 2016) was rasterized to delineate forest, water, grassland, and agricultural areas into a land-cover grid with cells of $30 \times 30 \mathrm{~m}$. We defined agricultural areas as those used as crop fields or livestock pastures, with clearly visible boundaries. We considered areas that lacked forest cover but did not have clearly visible boundaries in aerial images to be grasslands. Given the small size (often $<30 \times 30 \mathrm{~m}$ ) and scattered nature of the village areas within the Park, we drew polygons of village areas at a scale of 1:10,00o and overlaid those on the land-cover grid. We defined village polygons as areas with at least two buildings visible in satellite imagery, and extended village boundaries to the surrounding forest edge or clear boundaries of other land-cover types. Thus, settlements officially recognized as a single village could comprise multiple polygons, allowing us to distinguish between settled areas and other land-cover types that separated different parts of a village. Secluded settlement locations where multiple buildings were visible in satellite imagery but that were not associated with official villages were also included in the village landcover type. We then categorized recorded fosa locations by the land-cover type of their position on the grid. We used step selection functions to generate 10 random movements from every recorded position to calculate Manly selection ratios (Manly et al., 2003), using the $R$ package adehabitat (Calenge, 2015). With the widesIII function we computed habitat use vs availability for each individual, using a $\chi^{2}$ test. To calculate Manly selection ratios, we condensed GPS data into temporal windows with a resolution of 8 hours, to minimize temporal and spatial autocorrelation (Frair et al., 2004).

All GPS collars were equipped with a three-axis accelerometer to record activity counts simultaneously with geographical coordinates at 20-minute intervals. The accelerometers detected acceleration relative to gravity, with activity counts calculated as the total number of active seconds (where tilt or acceleration/deceleration occurs in any combination of three planes of motion) within each time interval.

\section{Results}

\section{Home ranges}

We captured five adult and two juvenile fosas, and only the adults were fitted with GPS collars. Three of the collared individuals were captured in 2016 (two males, one female), and two in 2017 (one male, one female). We assigned individual identifiers based on sex and capture order (e.g. the first captured female is $\mathrm{F} 1$ ). We tracked fosas for $14-115$ days, yielding 215-2,110 recorded locations per individual (Table 1).

Fosas represented $58 \%$ (seven out of 12) of all carnivores captured, with several non-native species (three cats Felis catus, one dog Canis familiaris and one small Indian civet Viverricula indica) also captured in our traps.

Home range size was similar across individuals, with home ranges calculated with Brownian bridge movement models consistently smaller than those estimated by kernel densities (Table 1). The home ranges of all individuals overlapped, with more overlap occurring between dyads in 2016 
TABLE 1 Spatial data and home range calculations (estimated by kernel densities and Brownian bridge movement models) for each individual fosa Cryptoprocta ferox tracked in with GPS collars in Ankarafantsika National Park, Madagascar (Fig. 1).

\begin{tabular}{|c|c|c|c|c|c|c|c|c|}
\hline \multirow[b]{2}{*}{ Individual } & \multirow[b]{2}{*}{ Year } & \multirow{2}{*}{$\begin{array}{l}\mathrm{N} \text { days } \\
\text { tracked }\end{array}$} & \multirow{2}{*}{$\begin{array}{l}\mathrm{N} \\
\text { locations }\end{array}$} & \multicolumn{3}{|c|}{ Kernel density estimate home range $\left(\mathrm{km}^{2}\right)$} & \multicolumn{2}{|c|}{$\begin{array}{l}\text { Brownian bridge movement } \\
\text { model home range }\left(\mathrm{km}^{2}\right)\end{array}$} \\
\hline & & & & $50 \%$ & $90 \%$ & $95 \%$ & $50 \%$ & $95 \%$ \\
\hline M1 & 2016 & 88 & 2,110 & 49 & 128 & 154 & 25 & 108 \\
\hline M2 & 2016 & 14 & 215 & 43 & 144 & 176 & 15 & 86 \\
\hline $\mathrm{F} 1$ & 2016 & 77 & 1,988 & 67 & 180 & 219 & 20 & 118 \\
\hline M3 & 2017 & 74 & 1,514 & 71 & 192 & 224 & 17 & 102 \\
\hline $\mathrm{F} 2$ & 2017 & 115 & 2,063 & 43 & 122 & 153 & 14 & 83 \\
\hline$M e a n \pm S E$ & & & & $54.6 \pm 6.0$ & $153.2 \pm 14.0$ & $185.0 \pm 15.0$ & $18.2 \pm 2.0$ & $99.4 \pm 6.6$ \\
\hline
\end{tabular}

TABLE 2 Overlap of each home range type (estimated by kernel densities and Brownian bridge movement models) for each fosa dyad, with values representing the percentage of individual 1's home range overlapping with that of individual 2.

\begin{tabular}{|c|c|c|c|c|c|c|c|}
\hline \multirow[b]{2}{*}{ Individual 1} & \multirow[b]{2}{*}{ Individual 2} & \multirow[b]{2}{*}{ Year } & \multicolumn{3}{|c|}{$\begin{array}{l}\text { Kernel density estimates } \\
(\% \text { overlap })\end{array}$} & \multicolumn{2}{|c|}{$\begin{array}{l}\text { Brownian bridge movement } \\
\text { models ( } \% \text { overlap) }\end{array}$} \\
\hline & & & $50 \%$ & $90 \%$ & $95 \%$ & $50 \%$ & $95 \%$ \\
\hline M1 & M2 & 2016 & 28 & 69 & 72 & 29 & 50 \\
\hline M2 & M1 & 2016 & 35 & 67 & 69 & 49 & 63 \\
\hline M1 & $\mathrm{F} 1$ & 2016 & 72 & 95 & 91 & 24 & 71 \\
\hline $\mathrm{F} 1$ & M1 & 2016 & 53 & 68 & 65 & 30 & 65 \\
\hline $\mathrm{F} 1$ & M2 & 2016 & 11 & 47 & 49 & 7 & 34 \\
\hline M2 & $\mathrm{F} 1$ & 2016 & 19 & 64 & 67 & 9 & 47 \\
\hline M3 & $\mathrm{F} 2$ & 2017 & 0 & 1 & 8 & 0 & 2 \\
\hline $\mathrm{F} 2$ & M3 & 2017 & 0 & 2 & 11 & 0 & 2 \\
\hline
\end{tabular}

than in 2017 (Table 2). In 2017, M3 and F2 home ranges occupied almost entirely separate spaces, with a maximum overlap of $11 \%$. The $\mathrm{RN}_{4}$ road did not appear to be a physical boundary for individuals, with collared fosas regularly crossing it in 2016. In $2017 \mathrm{M}_{3}$ travelled along the road on multiple occasions without crossing it, and $\mathrm{F}_{2}$ travelled near the road only once (Fig. 2). One individual collared in $2016(\mathrm{M} 2)$ was killed on the road in a vehicle collision (Wyza et al., 2018), demonstrating that $\mathrm{RN}_{4}$ poses a mortality risk.

\section{Habitat selection and avoidance of villages}

We calculated habitat selection for all individuals except $\mathrm{M}_{2}$ (Table 1). M2 had fewer recorded locations and could not be directly compared to other individuals in data compressed for Manly selection ratio analysis because the observation period was truncated by road mortality. Habitat selection was non-random, with all individuals in the analysis strongly preferring forested habitat (selection ratio $>_{1}$; Fig. 3). All other habitats were generally selected against (selection ratio $<1$ ), with variation in avoidance patterns across individuals. In particular, agricultural and village areas were universally selected against. Fewer than $0.1 \%$ (6 of 7,210) of recorded positions across all individuals were within village boundaries. We added a $30 \mathrm{~m}$ buffer to village boundaries to examine whether fosas used habitats at the village edge, but only 38 of 7,210 locations $(<1 \%)$ were recorded within the village buffer areas. All records within village boundaries were of males (one record of $\mathrm{M} 1$, three of $\mathrm{M}_{2}$ and two of $\mathrm{M}_{3}$ ).

Habitat composition of home ranges was similar across individuals, reflecting the high degree of spatial overlap between individual home ranges. Mean values for selection of habitat types within $95 \%$ kernel density estimate home ranges were forest $=0.732 \pm \mathrm{SE} 0.048$, grassland $=0.162 \pm \mathrm{SE}$ 0.043 , water $=0.003 \pm \mathrm{SE} 0.001$, agriculture $=0.098 \pm \mathrm{SE}$ 0.029 and village $=0.005 \pm$ SE 0.001 (Table 3 ). This confirms strong selection for forest habitats, with forest consistently occupying the highest proportion of each fosa's home range, and other land-cover types encompassing $<50 \%$ of all habitats within home ranges.

\section{Activity patterns}

Active periods (activity count $\geq 100$ ) of collared fosas occurred across all hours of the day, with resting periods primarily during 5.00-12.00. Overall, fosas exhibited a 

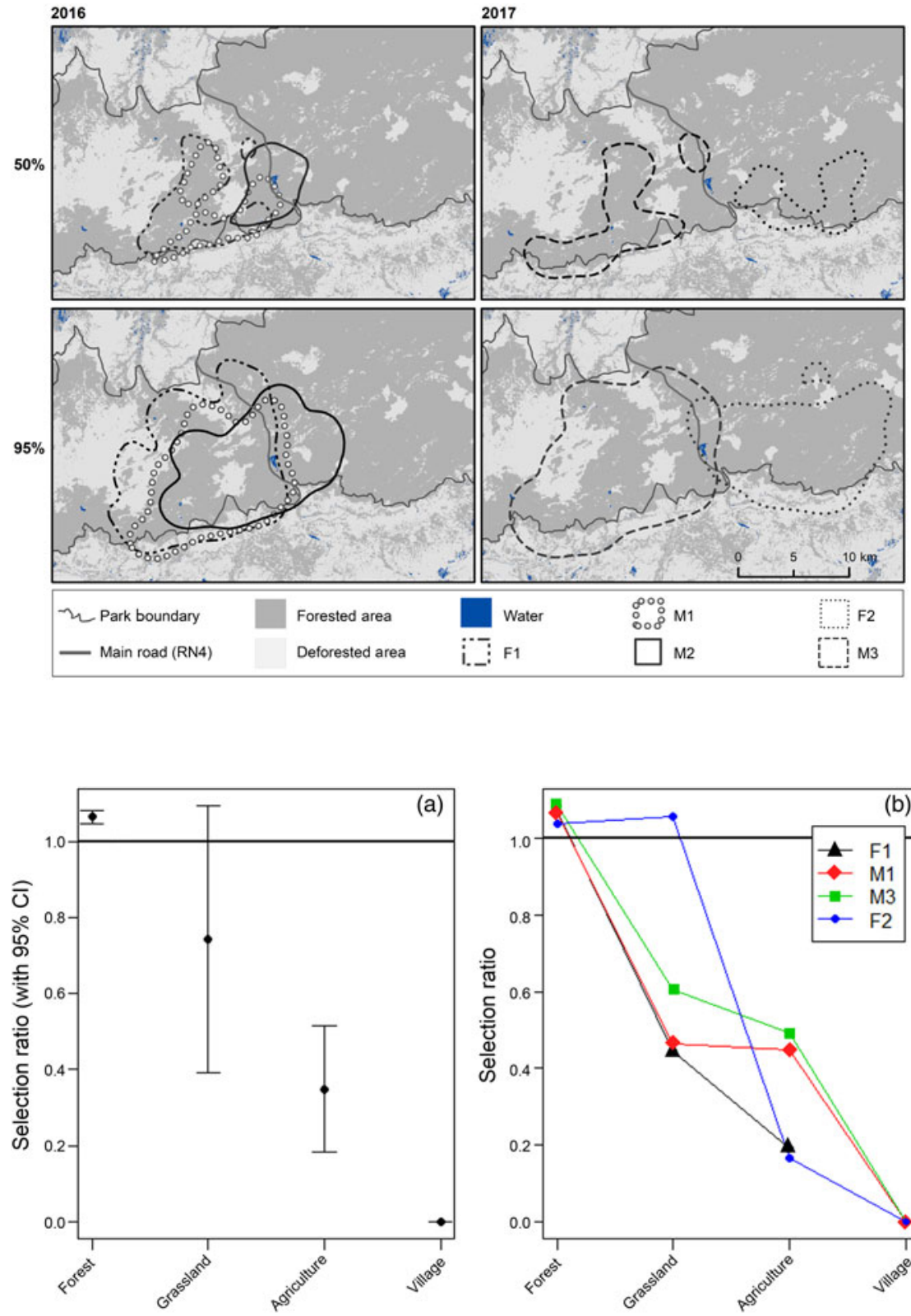

FIG. 2 Overlap of $50 \%$ and $95 \%$ kernel density estimate home ranges for individual fosas in 2016 and 2017. Each individual's home range perimeter is indicated by a different line.
TABLE 3 Proportion of land-cover types in individual fosas' home ranges estimated by $95 \%$ kernel densities.

\begin{tabular}{llllll}
\hline Individual & Forest & Grassland & Water & Agriculture & Village \\
\hline M1 & 0.698 & 0.093 & 0.001 & 0.204 & 0.004 \\
M2 & 0.856 & 0.098 & 0.000 & 0.038 & 0.008 \\
F1 & 0.653 & 0.269 & 0.006 & 0.070 & 0.002 \\
M3 & 0.619 & 0.265 & 0.005 & 0.109 & 0.002 \\
F2 & 0.835 & 0.087 & 0.003 & 0.068 & 0.007 \\
\hline
\end{tabular}

cathemeral pattern with a selective preference for crepuscular hours across all habitat types (Fig. 4a). Extended resting periods occurred almost exclusively within forest habitats, with mostly relatively high activity counts in other habitat types. Only $3 \%$ of inactive locations $(91$ of 3,159$)$ were outside the forest.
We separated activity counts by active (activity count $\geq 100$ ) and inactive (activity count $<100$ ) for each habitat type and found most locations recorded in non-forest habitat were during active periods (Fig. 4b). The percentages of active periods in non-forest habitats were agriculture $=96 \%(139$ of 144 locations), grassland $=82 \%$ ( 389 of 473 ), water $=100 \%$ ( 21 of 21 ) and village $=66 \%$ ( 4 of 6 ). In contrast, only $57 \%$ of locations in forest were during active periods.

\section{Use of forest corridors and patches}

Forest patches and corridors are present in the western part of the Park as a result of extensive deforestation (Fig. 1). Patches (forested areas surrounded by deforested areas) 
(a)
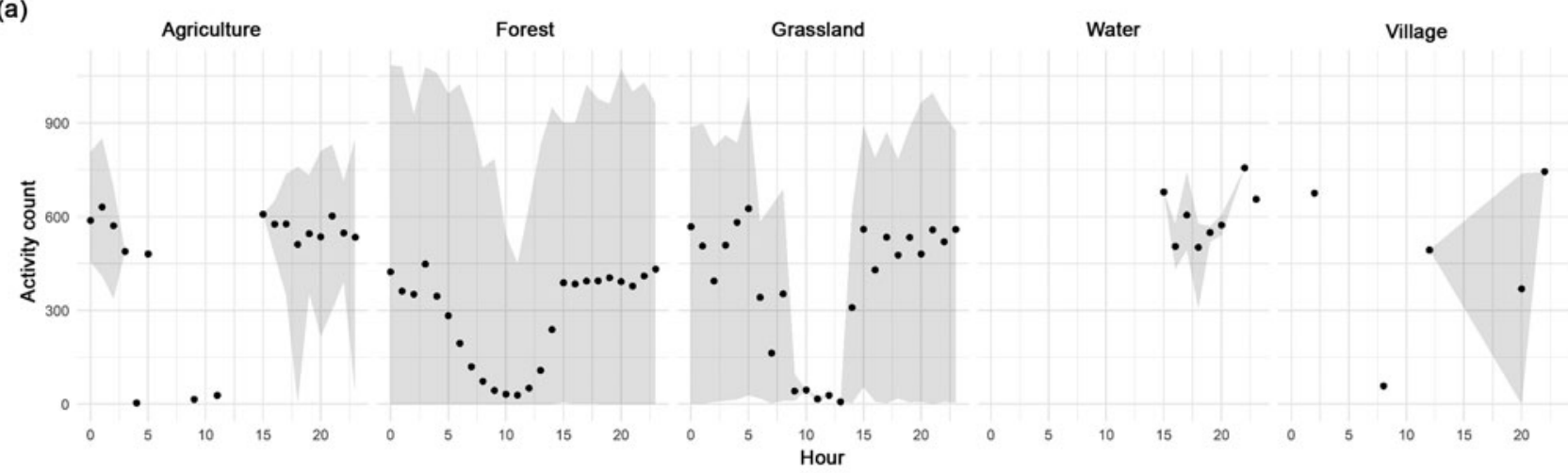

(b)
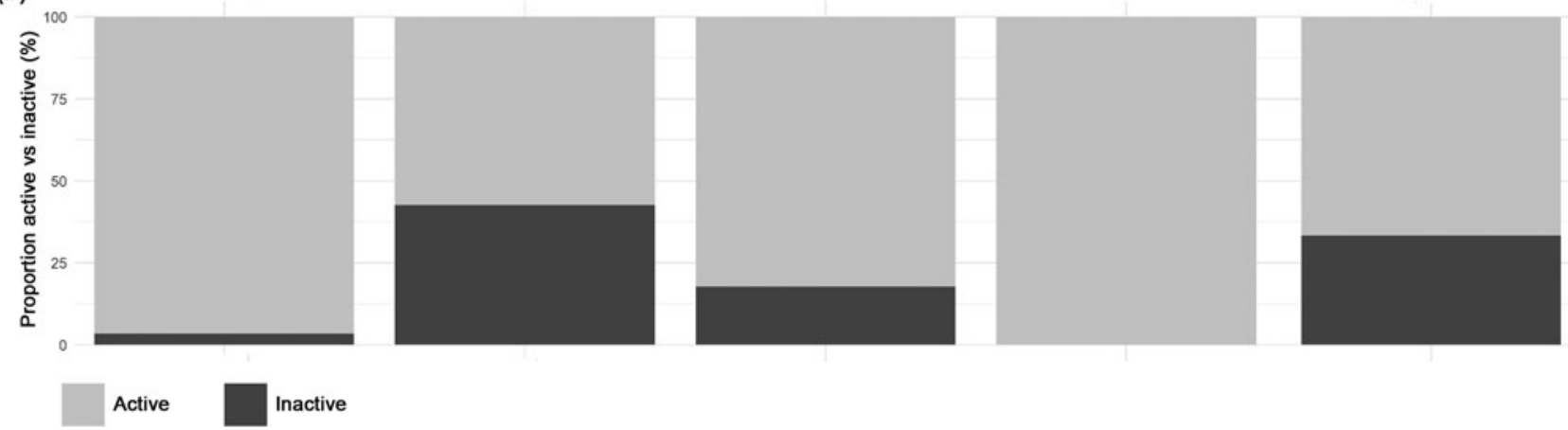

FIG. 4 Temporal patterns of fosas by land-cover type. (a) Mean activity patterns by hour across all individuals, with the dotted black line representing mean activity count, and shaded regions depicting the full range of activity counts recorded by hour. (b) Proportion of active (activity count $\geq 100$ ) and inactive (activity count $<100$ ) by land-cover type.
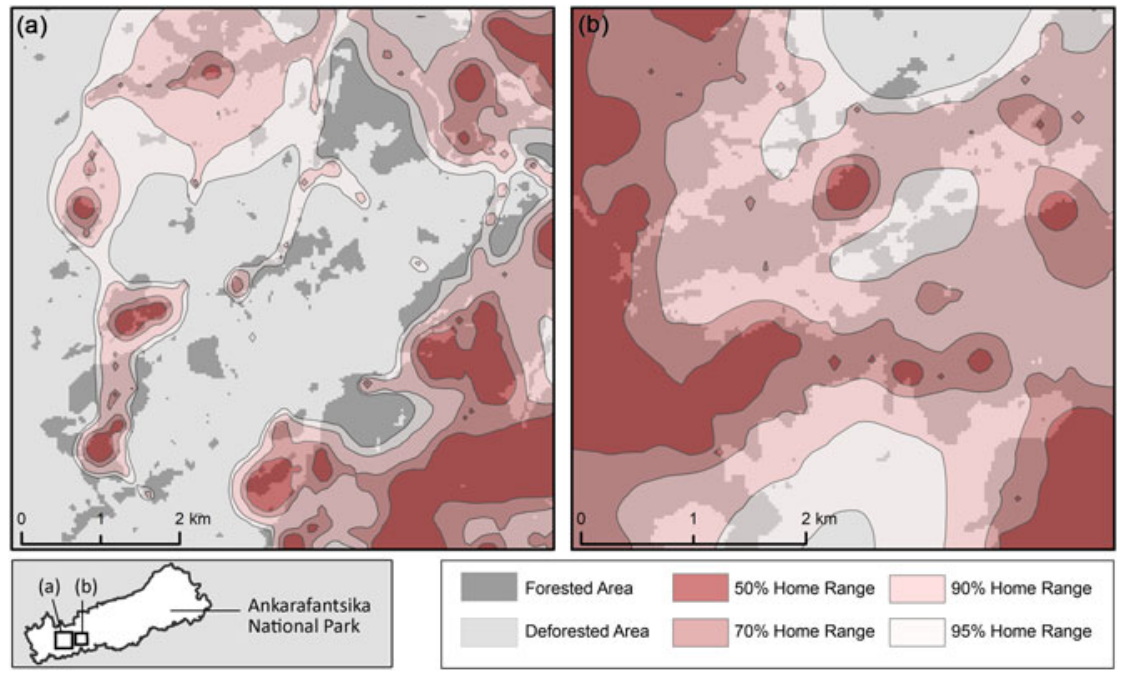

FIG. 5 Forest corridor use by in fosas in Ankarafantsika National Park. Brownian bridge movement model home ranges exhibit movements through forest patches and corridors across deforested landscapes: (a) F1 utilizing forest patches, (b) M1 utilizing corridors. ranged in size from $<10$ trees to $\leq 1 \mathrm{~km}$ wide, and corridors (forest strips connecting forested areas that would otherwise be separated) were $85^{-400} \mathrm{~m}$ wide and $0.4^{-1} \mathrm{~km}$ long. All collared fosas used forest patches and corridors to cross deforested areas throughout the study area (Fig. 5). Continuous forest corridors between grasslands were used particularly regularly by all individuals, and were included in the $50 \%$ Brownian bridge movement model home ranges of two individuals (F1 and M1; Fig. 5). In addition, $\mathrm{M}_{2}$ and
F2 used a c. $300 \mathrm{~m}$ wide corridor in the eastern part of the study area twice each during the study period. Corridors were traversed during $8.00-18.00$ and were sometimes used for resting.

Fosas also used forest patches when crossing deforested areas, although less often than continuous corridors. The patch network consisted of three larger and a series of smaller forest patches surrounded by open grassland (Fig. 5). Individuals $\mathrm{F}_{1}$ (three times, in 2016) and $\mathrm{M}_{3}$ (four times, 
in 2017) utilized these forest patches to cross grassland areas. Fosas used patches at similar times as corridors (8.00-18.0o). Activity counts for $\mathrm{F}_{1}$ and $\mathrm{M}_{3}$ reached a resting point (activity count $=0$ ) in several forest patches while traversing grasslands.

\section{Discussion}

Fine-scale movements and activity patterns of collared fosas revealed several overall patterns in home range and habitat selection: (1) dry season home range sizes in Ankarafantsika National Park were much larger than documented for fosas in Kirindy Forest, another dry deciduous forest, or protected rainforests in eastern Madagascar, with varying degrees of overlap between individuals; (2) individuals generally avoided open habitats and villages; (3) all fosas utilized forest patches or corridors to cross deforested areas. Additionally, accelerometer data documented that fosas remained active when traversing non-forested areas.

\section{Home ranges}

The high degree of home range overlap among the three individuals collared in 2016 is similar to the pattern observed in Kirindy Forest (Lührs \& Kappeler, 2013), with male home ranges overlapping those of females and other males. Previous studies at Kirindy documented males with larger home ranges than females (Hawkins, 1998), whereas home range sizes for males and females were similar in Ankarafantsika National Park. Overlap patterns for collared individuals were very different across years; the reasons for this could not be determined because of the small sample size.

Home range sizes estimated by kernel densities in Ankarafantsika National Park far exceeded those reported in Kirindy during the same season (Hawkins, 1998; Lührs \& Kappeler, 2013). This could potentially be a result of the longer monitoring duration in our study (GPS-collared fosas were tracked for a maximum of 1 month by Lührs \& Kappeler, 2013); however, fosas tracked via radio telemetry during both dry and wet seasons also had significantly smaller home ranges (Hawkins, 1998). Larger fosa home ranges in Ankarafantsika National Park may reflect the fact that the landscape is more fragmented than in Kirindy. Prey availability could be lower in fragmented habitats, resulting in fosas requiring larger home ranges to meet their nutritional requirements (McNab, 1963; Gittleman \& Harvey, 1982). Habitat fragmentation appears to influence the distribution of at least two of the large-bodied lemurs in the Park (Propithecus coquereli and Lepilemur edwardsi), which historically comprised much of the fosa's diet (Dollar et al., 2007), and may also affect other lemurs in the region (e.g. Eulemur fulvus and Eulemur mon$g o z)$. Home range overlap documented for fosas in the Park suggests there may be intraspecific competition for prey (Craul et al., 2009; Kun-Rodrigues et al., 2014).
Habitat selection and avoidance of villages

All collared individuals exhibited similar habitat selection for forest environments. Because their habitat is fragmented and their home ranges overlap, fosas in Ankarafantsika National Park are probably affected by the same villages, agricultural plots and deforested areas.

Habitat preferences varied slightly between individuals, but all generally avoided highly human-modified landscapes (agricultural areas and villages). All fosas used forest fragments, occupying edge habitat up to $2.5 \mathrm{~km}$ outside the Park boundary on several occasions. A recent camera-trap study in north-eastern Madagascar also reported open habitat avoidance, with similar habitat-use patterns outside contiguous forest patches (Farris et al., 2014), and work in central-eastern Madagascar documented fosa use of forest fragments up to $15 \mathrm{~km}$ from contiguous forests, with higher population density in fragments closer to contiguous forest habitats (Gerber et al., 2012).

Fosas in the Park tended to avoid areas of human habitation, including areas with only a few buildings. If fosas preyed upon poultry or other domestic animals, they could be expected to select positively for village areas. There may be areas of human occupation too small to be visible in satellite images, or hidden by tree canopy, thus documenting village encroachment into the Park's forested areas at a fine scale is necessary to gain further insights into fosa interactions with livestock and humans. The individual (M2) that most frequently entered villages was killed by a vehicle on the $\mathrm{RN}_{4}$ road, confirming that motor traffic is a threat to fosas (Wyza et al., 2018).

Persecution and hunting threaten fosa populations (Farris et al., 2015b; Hawkins, 2016) and occur mostly because people believe that fosas prey on poultry (Kotschwar Logan et al., 2015). In our study, $<1 \%$ of all recorded locations of the three collared males were in villages, and females never entered villages. Furthermore, $<_{1} \%$ of all recorded locations were within a $30 \mathrm{~m}$ buffer around village areas, indicating that during our study fosas did not spend a significant amount of time in or near villages. The median distance (across all individuals) of recorded locations to the nearest village boundary was $>2 \mathrm{~km}$, suggesting that fosas prefer the forest interior, rarely approach human settlements and probably do not rely on poultry as a major food source.

\section{Activity patterns}

Fosas in Ankarafantsika National Park did not appear to shift temporal activity patterns to avoid humans. A shift to more nocturnal activity patterns has been observed in other carnivore species in areas with frequent human activity. For example, brown bears Ursus arctos restrict active periods to twilight and night-time in areas with high road densities (Ordiz et al., 2014), and avoid humans by staying 
in areas of low human disturbance during times of high human activity (Martin et al., 2010). Lions Panthera leo in human-dominated landscapes alter prey preferences and shift temporal activity to avoid humans (Valeix et al., 2012). Fosas generally exhibit an irregular activity pattern, so fine-scale alterations may be difficult to detect. Fosas in other protected areas have been reported to alter activity patterns to avoid non-native carnivores (Farris et al., 2015a); however, fosas in Ankarafantsika National Park appear to exhibit irregular activity patterns with a preference for crepuscular hours, as documented in previous studies (Albignac, 1973; Hawkins, 1998; Gerber et al., 2012). The preference for crepuscular hours may reduce temporal overlap with humans, making it unnecessary for fosas to restrict their activities to nocturnal hours. A study in the Park that examined fosa and exotic carnivore activity patterns found fosas were active at different times compared to dogs and humans (Merson et al., 2018).

Fosas may also avoid humans and exotic carnivores by limiting extended resting periods to forest habitats. Almost all inactive positions recorded in our study were in the forest, suggesting fosas move through areas where they may encounter humans without extended pauses. Overall, our findings suggest that fosas primarily alter spatial rather than temporal activity patterns to avoid exotic carnivores or humans.

\section{Use of forest corridors and patches}

To our knowledge, this study is the first to document fosas habitually utilizing forest patches and corridors to traverse deforested areas. Previous camera-trap studies have recorded fosas in patchy forested areas, but the extent of use was unclear (Gerber et al., 2012; Kotschwar Logan et al., 2015).

Other forest-dependent carnivores utilize habitat patches and corridors to move across fragmented landscapes. The European pine marten Martes martes exhibits great plasticity in landscape use and has been observed traversing riparian corridors in heavily cultivated areas (Pereboom et al., 2008; Balestrieri et al., 2015). Fishers Martes pennanti habitually use forested corridors (LaPoint et al., 2013). The presence of corridors within fragmented landscapes appears critical for many forest-dwelling carnivores to maintain population connectivity and sufficient genetic diversity for long-term survival. The importance of corridors has been discussed in the context of climate change for both the American marten Martes americana (Wasserman et al., 2013) and the Canada lynx Lynx canadensis (Squires et al., 2013).

If habitats are disconnected, forest-dependent species can become isolated and vulnerable to local extinction pressures (Schüßlera et al., 2018). The fosa is already subject to isolation as a result of habitat fragmentation, particularly in western Madagascar where protected areas are situated among human-altered landscapes. Maintaining corridors within Ankarafantsika National Park, which hosts one of the last remaining viable fosa breeding populations, appears critical for population connectivity between its western and eastern sectors.

\section{Conservation implications}

In conclusion, our results suggest fosas respond to human encroachment by using forest corridors and patches to traverse a fragmented forest landscape. They appear to avoid human-dominated areas, but their large home ranges in Ankarafantsika National Park may reflect prey scarcity and competition with non-native carnivores such as domestic cats and dogs, and small Indian civets. Non-native carnivores collectively represented $42 \%$ of the carnivores trapped during our study, and additional individuals were observed on camera traps. The fosa's behaviour may be more flexible than previously thought, allowing the species to persist despite human disturbance, at least in the short term. Long-term viability will depend on a mixed strategy of maintaining and developing functional connectivity amongst fosa populations, whereby even modest forest corridors can facilitate dispersal and gene flow. If fosas in other areas of Madagascar show similar activity patterns as the ones tracked in our study, persecution could be reduced by sharing data on fosa diet and ranging patterns with local stakeholders, and carefully monitoring any threats fosas pose to local livelihoods. Although fosas appear to tolerate human encroachment to a degree and generally avoid areas of human habitation, dwindling and increasingly fragmented forests, together with competition from non-native carnivores, present ongoing threats to the species' persistence and increase the risk that Madagascar's apex predator will vanish from the island's ecosystems.

Acknowledgements We acknowledge funding for GPS collars from Naples Zoo and Collier Schools in Naples, USA. National Geographic Society supported LJD; Voinovich School of Leadership and Public Affairs at OHIO supported EW graduate funding and NJS project support. G. Dabelko contributed to project design. Heritage College of Osteopathic Medicine, Ohio, provided NJS research infrastructure and support. We thank the Editor and reviewers for their critiques. This paper is dedicated to the memory of colleague and co-author LPR.

Author contributions Study design: NJS, EW, LJD; provision of radio-collars: LJD; organization of permissions, logistical support: LD, LPR; fieldwork: EW, LD, LPR; data analysis: EW, VP; writing: EW, NJS.

\section{Conflicts of interest None.}

Ethical standards This research abided by the Oryx guidelines on ethical standards. Permits were acquired to conduct field work in Ankarafantsika National Park in accordance with an Institutional Animal Care and Use Committee protocol regarding capture of animals (Protocol \#17-H-013). 


\section{References}

Abay, G.Y., Bauer, H., Gebrihimot, K. \& Deckers, J. (2011) Peri-urban spotted hyena (Crocuta crocuta) in northern Ethiopia: diet, economic impact, and abundance. European Journal of Wildlife Research, 57, 759-765.

Albignac, R. (1973) Mammifere carnivores. Faune de Madagascar, $36,1-208$.

Alonso, L.E., Missa, O., Schulenberg, T.S. \& Radilofe, S. (2002) A Biological Assessment of the Réserve Naturelle Intégrale of d'Ankarafantsika, Madagascar, 1st edition. Conservation International, Arlington, USA.

Balestrieri, A., Remonti, L., Ruiz-Gonzalez, A., Zenato, M., Gazzola, A., Vergara, M. et al. (2015) Distribution and habitat use by pine marten Martes martes in a riparian corridor crossing intensively cultivated lowlands. Ecological Research, 30, 153-162.

Brown, D., Kays, R., Wikelski, M., Wilson, R. \& Klimley, A.P. (2013) Observing the unwatchable through acceleration logging of animal behavior. Animal Biotelemetry, 1, 20.

CALENGE, C. (2015) adehabitatHR: analysis of habitat selection by animals. R package version 1.8.18. cran.r-project.org/web/packages/ adehabitatHR/index.html [accessed 22 November 2019].

Condego, L. (2016) Semi-Automatic Classification Plugin Documentation. Plugin version 5.3.8. dx.doi.org/10.13140/RG.2.2. 29474.02242/1 [accessed 22 November 2019].

Cornell University (2002) ILO Census Data. ilo.cornell.edu/ilo/ data.html [accessed 7 March 2019].

Craul, M., Chikhi, L., Sousa, V., Olivieri, G.L., Rabesandratana, A., Zimmermann, E. \& Radespiel, U. (2009) Influence of forest fragmentation on an endangered large-bodied lemur in northwestern Madagascar. Biological Conservation, 142, 2862-2871.

Dollar, L. (2006) Morphometrics, diet, and conservation of Cryptoprocta ferox. PhD dissertation, Duke University, Durham, USA.

Dollar, L., Ganzhorn, J.U. \& Goodman, S.M. (2007) Primates and other prey in the seasonally variable diet of Cryptoprocta ferox in the dry deciduous forest of western Madagascar. In Primate AntiPredator Strategies (Developments in Primatology: Progress and Prospects) (eds S.L. Gursky \& K.A.I. Nekaris), pp. 63-76. Springer, Berlin, Germany.

Farris, Z.J., Karpanty, S.M., Ratelolahy, F. \& Kelly, M.J. (2014) Predator-primate distribution, activity, and co-occurrence in relation to habitat and human activity across fragmented and contiguous forests in Northeastern Madagascar. International Journal of Primatology, 35, 859-88o.

Farris, Z.J., Gerber, B.D., Karpanty, S., Murphy, A., Andrianjakarivelo, A., Ratelolahy, F. \& Kelly, M.J. (2015a) When carnivores roam: temporal patterns and overlap among Madagascar's native and exotic carnivores. Journal of Zoology, 296, 45-57.

Farris, Z.J., Golden, C.D., Karpanty, S., Murphy, A., Stauffer, D. \& Ratelolahy, F. (2015b) Hunting, exotic carnivores, and habitat loss: anthropogenic effects on a native carnivore community, Madagascar. PLOS ONE, 10, eo136456.

Frair, J.L., Nielson, S.E., Merril, E.H., Lele, S.R., Boyse, M.S., Munro, R.H.M. et al. (2004) Removing GPS collar bias in habitat selection studies. Journal of Applied Ecology, 41, 201-212.

García, G. \& Goodman, S.M., (2003) Hunting of protected animals in the Parc National d'Ankarafantsika, north-western Madagascar. Oryx, 37, 115-118.

Gerber, B.D., Karpanty, S.M., Crawford, C., Kotschwar, M. \& RANDRIANANTENAina, J. (2010) An assessment of carnivore relative abundance and density in the eastern rainforests of Madagascar using remotely-triggered camera traps. Oryx, 44, 219-222.
Gerber, B.D., Karpanty, S.M. \& Randrianantenaina, J. (2012) Activity patterns of carnivores in the rain forests of Madagascar: implications for species coexistence. Journal of Mammalogy, 93, 667-676.

Gittleman, J.L. \& Harvey, P.H. (1982) Carnivore home-range size, metabolic needs, and ecology. Behavioral Ecology and Sociobiology, $10,57-63$.

Gloor, S., Bontadina, F., Hegglin, D., Deplazes, P. \& Breitenmoser, U. (2001) The rise of urban fox populations in Switzerland. Mammalian Biology, 66, 155-164.

Golden, C.D. (2009) Bushmeat hunting and use in the Makira forest, north-eastern Madagascar: a conservation and livelihoods issue. Oryx, 43, 386-392.

Grubbs, S.E. \& Krausman, P.R. (2009) Use of urban landscapes by coyotes. The Southwestern Naturalist, 54, 1-12.

Harper, G.K., Steininger, M.K., Tucker, C.J., Juhn, D. \& Hawkins, F. (2007) Fifty years of deforestation and forest fragmentation in Madagascar. Environmental Conservation, 34, 1-9.

HaW KIns, C.E. (1998) The behaviour and ecology of the fossa, Cryptoprocta ferox (Carnivora: Viverridae) in a dry deciduous forest in western Madagascar. $\mathrm{PhD}$ thesis, University of Aberdeen, Aberdeen, UK.

Haw kins, C.E. (2003) Cryptoprocta ferox, fossa, fosa. In The Natural History of Madagascar (eds S.M. Goodman \& J.P. Benstead), pp. 1361-1363. The University of Chicago Press, Chicago, USA.

HAWKINS, C.E. \& RACEY, P.A. (2005) Low population density of a tropical forest carnivore, Cryptoprocta ferox: implications for protected area management. Oryx, 39, 35-43.

Hawkins, F. (2016) Cryptoprocta ferox. In The IUCN Red List of Threatened Species 2016. dx.doi.org/10.2305/IUCN.UK.2016-1.RLTS. T5760A45197189.en [accessed 15 October 2016].

Horne, J.S., Garton, E.O., Krone, S.M. \& Lewis, J.S. (2007) Analyzing animal movements using Brownian bridges. Ecology, 88, 2354-2363.

KöhnCKe, M. \& Leonhardt, K. (1986) Cryptoprocta ferox. Mammalian Species, 254, 1-5.

Kotschwar Logan, M., Gerber, B.D., Karpanty, S.M., Justin, S. \& Rabenahy, F.N. (2015) Assessing carnivore distribution from local knowledge across a human-dominated landscape in central-southeastern Madagascar. Animal Conservation, 18, 82-91.

Kun-Rodrigues, C., Salmona, J., Besolo, A., Rasolondraibe, E., Rabarivola, C., Marques, T.A. \& Chikhi, L. (2014) New density estimates of a threatened sifaka species (Propithecus coquereli) in Ankarafantsika National Park. American Journal of Primatology, $76,515-528$.

LaPoint, S., Gallery, P., Wikelski, M. \& Kays, R. (2013) Animal behavior, cost-based corridor models, and real corridors. Landscape Ecology, 28, 1615-1630.

Lührs, M.L. \& Kappeler, P. (2013) Simultaneous GPS tracking reveals male associations in a solitary carnivore. Behavioral Ecology and Sociobiology, 67, 1731-1743.

Manly, B.F.J., McDonald, L.L., Thomas, D.L., McDonald, T.L. \& Erickson, W.P. (2003) Resource Selection by Animals - Statistical Design and Analysis for Field Studies. 2nd edition. Kluwer Academic Publishers, London.

Mann, G.K.H., Rakotondraparany, F., The Seing, S. \& Gandola, R. (2015) First record of fossa Cryptoprocta ferox in Mariarano Forest, Madagascar. Small Carnivore Conservation, 52 \& 53, 45-55.

Martin, J., Basile, M., Van Moorter, B., Kindberg, J., Allainé, D. \& Swenson, J.E. (2010) Coping with human disturbance: spatial and temporal tactics of the brown bear (Ursus arctos). Canadian Journal of Zoology, 88, 875-883.

$\mathrm{MCN}_{\mathrm{AB}}$, B.K. (1963) Bioenergetics and the determination of home range size. The American Naturalist, 97, 133-140. 
Merson, S.D., Dollar, L.J., Tan, C.K.W. \& Macdonald, D.W. (2018) Activity patterns of sympatric living exotic and endemic carnivores (the fosa) in Western Madagascar's deciduous forests. Journal of Zoology, 307, 186-194.

Morales, J.M. \& Elner, S.P. (2002) Scaling up animal movements in heterogeneous landscapes: the importance of behavior. Ecology, $83,2240-2247$.

Nathan, R., Spiegel, O., Fortmann-Roe, S., Harel, R., Wikelski, M. \& GeTZ, W. (2012) Using tri-axial acceleration data to identify behavioral modes of free-ranging animals: general concepts and tools illustrated for griffon vultures. The Journal of Experimental Biology, 215, 986-996.

Nielson, R.M., Sawyer, H. \& McDonald, T.L. (2015) BBMM. $R$ 3.3.2 package. CRAN.R-project.org/package $=\mathrm{BBMM}$ [accessed 24 July 2019].

Ordiz, A., Kindberg, J., SÆbø, S., Swenson, J.E. \& Støen, O. (2014) Brown bear circadian behavior reveals human environmental encroachment. Biological Conservation, 173, 1-9.

Pereboom, V., Mergey, M., Villerette, N., Helder, R., Gerard, J.F. \& Lode, T. (2008) Movement patterns, habitat selection, and corridor use of a typical woodland-dweller species, the European pine marten (Martes martes), in fragmented landscape. Canadian Journal of Zoology, 86, 983-991.

Pomerantz, J., Rasambainarivo, F.T., Dollar, L., Rahajanirina, L.P., Andrianaivoarivelo, R., Parker, P. \& Dubovi, E. (2016) Prevalence of antibodies to selected viruses and parasites in introduced and endemic carnivores in western Madagascar. Journal of Wildlife Disease, 52, 1-9.

Rahajanirina, L.P. (2003) Contribution a l'Etude Biologique, Ecologique et Etholoqiue de Cryptoprocta ferox (Benett 1883) dans la Region du lac Tsimaloto, Parc National d'Ankarafantsika, Madagascar. Memoire de DEA-Biologie Animale, Université d'Antananarivo, Antananarivo, Madagascar.

Riley, S.P.D., Sauvajot, R.M., Fuller, T.K., York, E.C., Kamradt, D.A., Bromley, C. \& Wayne, R.K. (2003) Effects of urbanization and habitat fragmentation on bobcats and coyotes in Southern California. Conservation Biology, 17, 566-576.

Schüßlera, D., Radespiel, U., Ratsimbazafy, J.H. \& Mantilla-Contreras, J. (2018) Lemurs in a dying forest: factors influencing lemur diversity and distribution in forest remnants of north-eastern Madagascar. Biological Conservation, 228, 17-26.

Shepard, E.L.C., Wilson, R., Quintana, F., Laich, A.G., Liebsch, N., Albareda, D.A. et al. (2008) Identification of animal movement patterns using tri-axial accelerometry. Endangered Species Research, $10,47-60$.

Squires, J.R., DeCesare, N.J., Olson, L.E., Kolbe, J.A., Hebblewhite, M. \& Parks, S.A. (2013) Combining resource selection and movement behavior to predict corridors for Canada lynx at their southern range periphery. Biological Conservation, $157,187-195$

U.S. Geological Survey (2016) Landsat Data Access. usgs.gov/ land-resources/nli/landsat/landsat-data-access [accessed 22 November 2019].

Valeix, M., Hemson, G., Loveridge, A.J., Mills, G. \& Macdonald, D.W. (2012) Behavioural adjustments of a large carnivore to access secondary prey in a human-dominated landscape. Journal of Applied Ecology, 49, 73-81.

Wang, Y., Smith, J.A. \& Wilmers, C.C. (2017) Residential development alters behavior, movement, and energetics in an apex predator, the puma. PLOS ONE, 12, e0184687.

Wasserman, T.N., Cushman, S.A., Littell, J.S., Shirk, A.J. \& Landguth, E.L. (2013) Population connectivity and genetic diversity of American marten (Martes americana) in the United States northern Rocky Mountains in a climate change context. Conservation Genetics, 14, 529-541.

Woodroffe, R. \& Ginsber G, J.R. (1998) Edge effects and the extinction of populations inside protected areas. Science, 280, 2126-2128.

Worton, B.J. (1989) Kernel methods for estimating the utilization distribution in home-range studies. Ecology, 70, 164-168.

Wyza, E., Dollar, L. \& Stevens, N. (2018) First evidence of male spatial associations and roadkill mortality in the fosa Cryptoprocta ferox in Ankarafantsika National Park, Madagascar. Small Carnivore Conservation, 56, 76-85.

Zinner, D., Wygoda, C., Razafimanantsoa, L., Rasoloarison, R., Andrianandrasana, H.T., Ganzhorn, J.U. \& Torkler, F. (2014) Analysis of deforestation patterns in central Menabe, Madagascar, between 1973 and 2010. Regional Environmental Change, 14, 157-166. 